Chapter 19

\title{
CORROSION STUDIES OF STEEL PILING IN SEA WATER IN BOSTON HARBOR
}

\author{
George L. Wey \\ Chief Engineer, Port of Boston Authority \\ Commonwealth Pier No. 5, South Boston, Mass.
}

\section{INTRODUCTION}

A vital problem whioh has resulted from our present eoonomic justification of the use of steel piles in all of the Port's waterfront terminals is the oorrosion of the piles in sea water. The selection of some type of steel piles was not made on the basis of greater resistanoe to fire and marine organisms, but for purely economic reasons. Timber piling has its marine borer problem, and steel has its corrosion. In this article there are three thoughts which I hope to oonvey to every engineer engrged in ooastal engineering, namely:

(1) Each project's corrosion consideration should be treated as a distinot and separate study in designing a pile-supported

structure, based on investigation of adjaoent looal conditions.

(2) There is nothing universal about the pattern or rate of corrosion to be expeoted; it is subjeot to many variables.

(3) Provisions or measures to mitigate or eliminate corrosion should have economio justification consistent with the planned life expeotancy of the study.

With the greater use of steel piles we naturally become more conscious of this vital problem of corrosion. In order to keep informed as to the correctness of our design criteria and to evaluate protective ooatings for the mitigation of oorrosion, the Authority has started a regular program for the periodic examination of steel pile structures in Boston Harbor. At the present time we have utilized outside marine divers in collaboration with the William $F$. Clapp Laboratories, Inc,, for our own structures. It is expected that we shall very shortly revive our own diving unit, which prior to World War II made examinations of all timber structures in the Harbor. The diver would have to undergo an extensive course in corrosion pattern reoognition, location of possible accelerated aotivity, measuring procedures and desoription of observations; otherwise the value of the work would be questionable. Whenever a steel pile is removed, regardless of by whom, we attempt to get all the oorrosion information and data before the pile is disposed of. We also have been most fortunate in obtaining the oooperation of other interests in the Harbor who have steel structures, in making similar examinations for their own information as to the existing oondition of the piles and for our compilation of corrosion data.

Investigation and studies made of existing structures in Boston Harbor indicated a great range of pattern and rates of corrosion which refute widespread oonoepts aocepted by many design engineers, such as that: 
COASTAL ENGINEERING

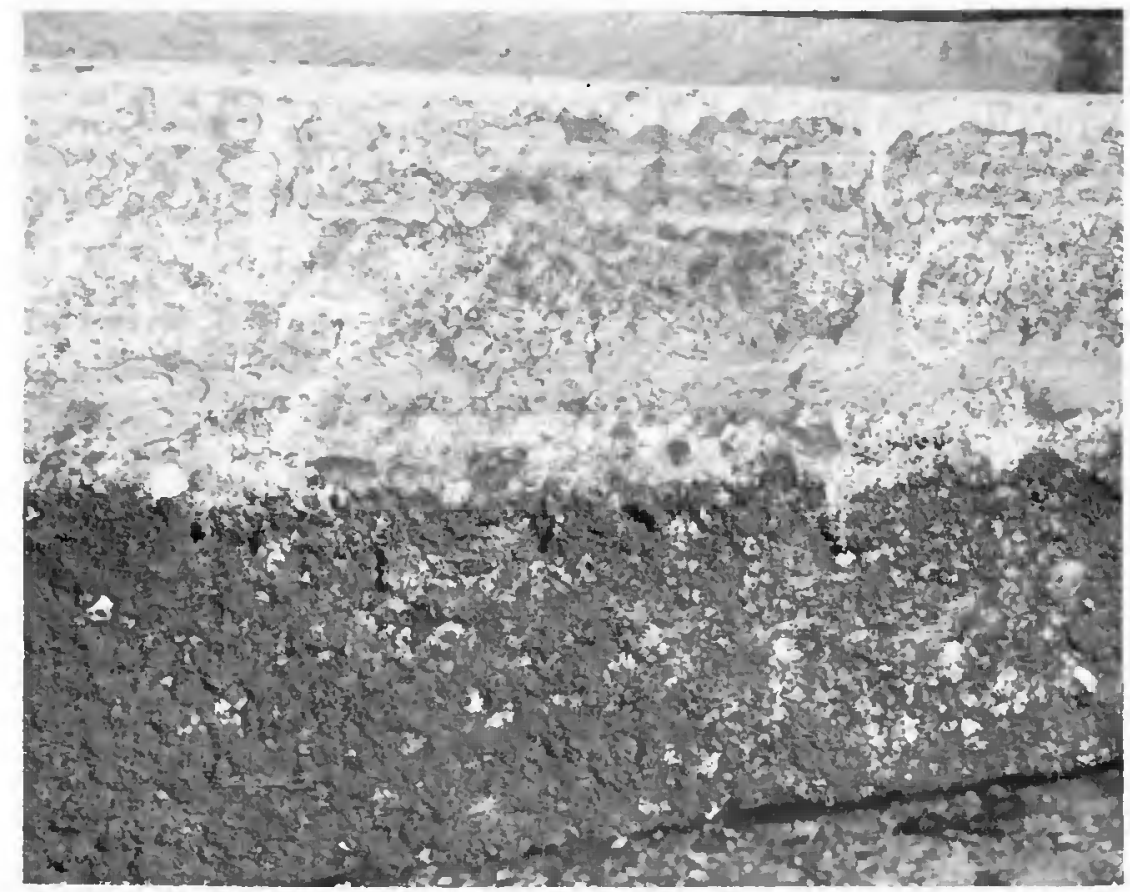

Fig. 1. Corrosion pattern on unenoesed pile.

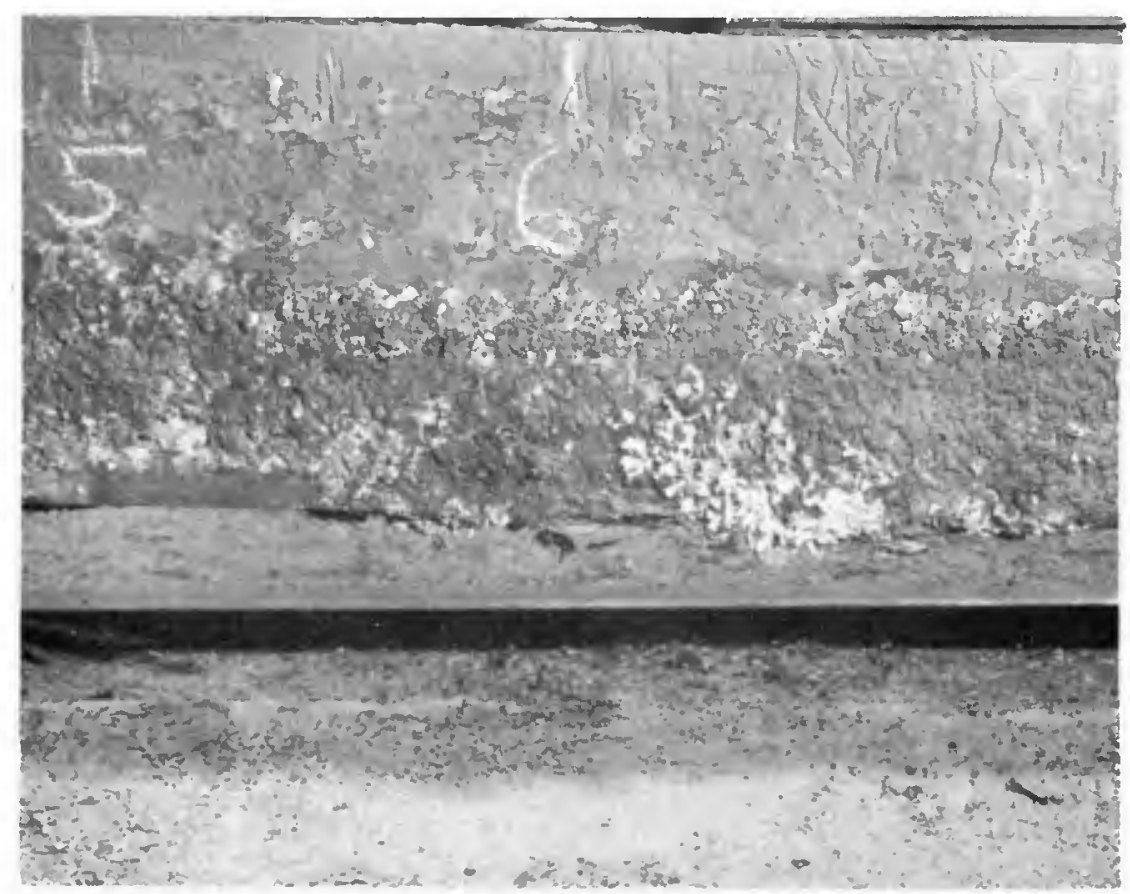

Fig. 2. Corrosion pattern on enoased pile. 


\section{CORROSION STUDIES OF STEEL PILING IN SEA WATER IN BOSTON HARBOR}

(1) Corrosion rate is uniform throughout the entire length of pilo, and that a 10 per cent additional allowance of steel in the section of the member would provide a life expeotancy of 40 to 50 years. The 10 per cent has been increased by many to 20 per oent.

(2) All types of steel piles have the same corrosion pattern and rate.

In this short article it is impossible to cover the subjeot with any degree of thoroughness. Some of the findings desoribed herein are no doubt startling to many. These are just a few of the actual conditions, to emphasize the need for better understanding of the problem, and not with any intention of being speotaoular.

\section{TYPICAL EXAMPLES}

At one looation two ste日l "H" bearing piles were removed from sea water after 11 years of service. These two were about 12 feet apart. One had concrete encasement to low water, and the other no protection of any kind. The corrosion pattern was entirely different in each case. The encased pile had a more or less uniform corrosion rate consisting mainly of grooves as shown on Figure 1. The plain pile had a severe attack at low water with a pattern consisting of pits as shown on Figure 2. The maximum loss of metal in the cross-section of the encased pile was about 3 per cent, whereas the other had a loss of 10.4 per cont occurring at approximately the extreme low water line, with an insignifioant loss for the remainder of the length. The loss of 10.4 per cont of the plain pile does not appear alarming until you analyze it from a structural standpoint. The loss occurred at the edges of the flanges, which would normally be expeoted in galvanio action resulting from the dirferential of oxygen concentration. Structurally the loss takes place in the worst part of the member, the weak axis.

As an example of the seriousness of this loss, take a 14 inch 73\# bearing pile with an unsupported length of 48 feet. A reduation in the radius of gyration from a 10 per cent loss of metal at the ends of the flanges results in a 44 per cent decrease in the allowable load on the pile. Under this degreo of oorrosion attaok it would be impraotioal and uneconomical to provide a sufficient cross-seotion of metal to sustain such a loss over a great period of time.

Since this accelerated attack took place below the normal water level and the pile was covered with a thick growth of marine organisms, discovery of the accolerated attack is not likely by visual observation. Unless periodio examinations by a competent diver are made to disoover such oritical conditions, collapse of the structure would be imminent.

Pursuing this investigation and study further along, the owners of a wharf made a random inspection of 8 piles in place, selected as representative of the areas in which each was located. This was done in order to verify the following finding: 


\section{COASTAL ENGINEERING}

Low water acoelerated attack does not ocour on the enossed piles, and grooving with a more or less uniform corrosion loss is also a characteristic of the encased piles.

This finding was found to be oorreot. It was also found that the seaward most piles had evidence of greater corrosion rate. The reason for the latter is rather difficult to explain, sinoe it ocourred not uniformly, but somewhere between the lower zone of a breaking wave and the location of the propeller of a deep-draft vessel. In attempting to ascertain the cause of the grooving corrosion pattern, a number of experts were consulted. It was the consensus of opinion that this peouliar pattern was caused by stress weaknesses in the mill soale as a result of the rolling, storage, transportation or handling prooess. The breaks in the mill soale become anodic and the soale oathodic in the galvanio cell. This is oridencod by the calcareous coating on the mill scale surrounding the corroded areas. The rather difficult observation to explain is the presenoe of no grooving on the plain pile, which had a pit pattern. The question remains as to whether this is a coinoidence or whether there is a definite relationship.

At the looation of our new Hoosao Pier No. I the former terminal had a steol sheot pile bulkhead which was installed in 1935 and removed in 1943. Thiokness measurements taken at the time of removal showed tremendous $108 s$ in a short period of time. At this point the salinity of the water is reduoed by an inflow of fresh water above this location, and is also polluted from a sewerage overflow disoharge line. Four random piles were measured, but there was no similarity of attack common to al1. The record contains no apparent cause for this abnormal severe attack, whioh contains very little looalized pitting. The logs or flanges of the DP 1 Section had a greater rate of corrosion than the web. The more or less uniform attack from the mud line to the top of the pile in the splash zone is difficult to understand in view of well-established concepts as to the areas of accelerated attack, namely, just below mean low water, and the splash zone above mean high water. At this looation in 1948 the steol sheot pile bulkhead type of quay wall was construoted for the new Hoosac Pier No. 1. Before driving the sheeting that portion above 3 feet below moan low water was flame cleaned of mill soale and rust, and then ooated with bitumastic enamel. Annually the shooting is examined by a diver for accelerated corrosion. To date nothing had developed requiring remedial action.

Also involved in the submarine examination of steel piles is our desire for information on grooving adjecent to welded splices caused by galvanio action between the bare motal at the weld, which is anodic, and the cathodic mill soale. To date we have found little evidence of such phenomena.

Cylindrical steel piles and caissons have also been examined, and found to have a good performanoe as regards corrosion. The absence of 


\section{CORROSION STUDIES OF STEEL PILING IN SEA WATER IN BOSTON HARBOR}

edges prevents gelvanic current concentrations, espeoially at the low water area. The caisson examination indicated a very puzzling observation. The caissons on the opposite side of the pier are not coatod. Because of the very large diameter, and the fact that they are filled with concrete, an acourate verification would be difficult. There is very littlo pitting, indicating a uniform pattern.

\section{ECONOMIC JSTIFICATION OF PROTECTION}

There are many protective systems to mitigate or completely eliminate corrosion for a given period. The anticipated life of the new piers of the Port of Boston Authority is between 40 and 50 years, after which the piers become obsolete, and should be reoonstructed to fit the needs of that time. Other stmuctures may have different iife expeotancies; therefore, the measures to attain the required life should be justified economioally consistent with the planned lifo, meaning that one with a 15-year life should not necessarily have the same protective measures as one with a 40-year life.

The greatest boost given to overooming sea water corrosion is cathodic protection, for it has proven positive, it can be installed at any time after completion of a stmuture, and it protects the most difficult seotion, which is below the surface of the water. Although cathodio protection is the only practical means of prohibiting corrosion below the surface of the water, there are many protective measures for the zone above, such as metal jackets, organio coatings, metal coatings, greases and wrapped plastic coats. In spite of the number of methods for the tidal and atmospherio zone, there is still a need for improvement - some of the methods are too expensive, and other have too short a life tor economic justification. There are many factors to be considered in protective coatings. The degree of preparation of the steel. surface required; setting time, especially for recoat jobs in the tidal zone; the number of applications for a complete system; resistance to abrasion; the size of the project; and the anticipated protective life. In sandblasting steel there are 3 classes which indicates the wide range one can expoct in cost and quality:

(1) Primary, which removes all loose scale and rust;

(2) Intermediate, which remores all scale to gray coating;

(3) Complete, all scale taken off to bright metal.

An average good coating will have an effective life of about 5 or 6 years. Poor coating, including poor workmanship, will fail in less than a year, with the best going to an 8 to 9 year life.

This is an example of the economic analysis that has been made on insuring a pier life expeotanoy of 40 to 50 -years as it affects the corrosion of piles. The recommended protective system in this case consists 
of cathodio protection below the water and organic coatings above. The cost of this system of protection for the period starting upon completion of the structure is as follows:

$$
\begin{aligned}
& \text { Cathodic Protection } \\
& \text { Protective Coatings, using } \\
& \text { re-coating every } 5 \text { years }
\end{aligned}
$$

$$
\begin{aligned}
& \$ 360,000 \\
& \$ 480,000 \\
& \hline \$ 840,000
\end{aligned}
$$

The steel sheet piles could be replaced in 20 years to stand up for another 20-year period, at a cost of $\$ 560,000$. This is the plan aocepted to insure the investment for the antioipated life.

The logioal action to take in many cases, if it is determined that protective measures will be needed immediately upon oompletion of a large waterfront structure, is to use a more costly type of substmacture whioh will not require a continuous protective program. However, in cases where accelerated oorrosion is discovered after completion of a structure, the only alternative is the system using cathodic protection for below water, and ooatings or jaokets above.

\section{CONCLUSION}

This article is intended to stimulate the need for giving more thought and analysis to each waterfront corrosion problem, for continual obserration of existing struotures, and researoh for more economioal protective measures. The findings and discussion herein precented are not meant to be taken as any oriteria for the oorrosion pattern, rate, and means of mitigating corrosion. It is impossible to oover adequately and properly in this short space the subject of marine corrosion of steel piling.

\section{ACKMONLEDGMENTS}

In connection with the compilation of corrosion data of 8 teel piles in Boston Harbor, I wish to take this opportunity to express my appreciation for the cooperation and assistance given me by Mr. A. P. Riohards, Direotor of the William F. Clapp Laboratories, Ino., Duxbury, Massachusetts; Commander A. C. Eusband, Public Works Officer, Boston Naval Shipyard; and Commander F. A. Tinsler, Distriot Engineer, Flrst Coast Guard Distriot. 